\title{
Penggunaan media gambar dalam sosialisasi sekolah tatap muka kepada anak sekolah dasar selama masa pandemi covid - 19
}

\author{
Siti Rohmawati*)1, Syarufah2, Krisna Suda Pratama3, Liswanti4, M. Said Agil L5, \\ Afriyadi Sofyan6 \\ ${ }^{1}$ Program Studi Kimia, Fakultas Matematika dan Ilmu Pengetahuan Alam, Universitas Negeri Semarang, Indonesia \\ ${ }^{2}$ Program Studi Ilmu Hukum, Fakultas Hukum, Universitas Negeri Semarang, Indonesia \\ ${ }^{3}$ Program Studi Desain Komunikasi Visual, Fakultas Bahasa dan Seni, Universitas Negeri Semarang, Indonesia \\ ${ }^{4}$ Program Studi Teknik Informatika, Fakultas Matematika dan Ilmu Pengetahuan Alam/ Universitas Negeri \\ Semarang, Indonesia \\ ${ }^{5}$ Program Studi Akuntansi, Fakultas Ekonomi, Universitas Negeri Semarang, Indonesia \\ ${ }^{6}$ Program Studi Bimbingan Konseling, Fakltas Ilmu Pendidikan, Universitas Negeri Semarang, Indonesia
}

\section{Article Info \\ Article history: \\ Received May $18^{\text {th }}, 2021$ \\ Revised Jun $24^{\text {th }}, 2021$ \\ Accepted Jul 27 $7^{\text {th }}, 2021$}

\section{Keyword:}

Image media,

Face-to-face school

Socialization,

Covid-19 health protocol

\begin{abstract}
ABSTRAK
Indonesia has been affected by the Covid-19 pandemic in the education sector. The government has suspended learning activities in both formal and non-formal schools to suppress the spread of Covid-19. Based on data from the Covid-19 Task Force, there has been a decline in Covid-19 cases in Indonesia. So that the Elementary School in Boloagung Village has started holding face-to-face meetings. Children need to get adequate information and easy-to-understand health protocols when starting face-to-face school. This service is carried out directly in Boloagung Village. This activity is intended for grade 1 to grade 6 children and the socialization is done by coloring the picture media. The image media presented is in the form of a series of simple images containing concise messages and information. The result of this program is that participants understand more about health protocols that are carried out during face-to-face schools. Participants were very enthusiastic about participating in this program.
\end{abstract}

(C) 2021 The Authors. Published by IICET

This is an open access article under the CC BY-NC-SA license

(https://creativecommons.org/licenses/by-nc-sa/4.0

\section{Corresponding Author:}

Rohmawati, S.,

$\equiv$ sitirohmawati@students.unnes.ac.id

\section{Pendahuluan}

Pada awal tahun 2020, dunia digemparkan oleh munculnya virus Corona atau Covid - 19 di Wuhan, China. Virus ini sudah ada di China sejak bulan Desember 2019, akan tetapi mulai menyebar pada tahun 2020. Covid - 19 mudah menular dan sangat cepat menyebar ke berbagai negara, sehingga dinamakan pandemi Covid - 19. Indonesia menjadi salah satu negara yang terkena pandemi Covid - 19 dan mulai terjadi penyebaran Covid - 19 pada bulan Maret 2020. Pandemi Covid - 19 berdampak pada bidang ekonomi, politik, sosial, dan juga pendidikan. Berbagai negara di dunia memberhentikan kegiatan pembelajaran baik itu di sekolah formal ataupun non formal guna mengurangi penyebaran Covid-19 termasuk Indonesia. Penerapan kebijakan yang diambil oleh pemerintah Indonesia ini dilakukan memberhentikan kegiatan pembelajaran secara total tidak terkecuali pada instansi manapun dan diberlakukan secara menyeluruh sampai pada pelosok negeri. (Marwanto, 2021)

Covid - 19 adalah corona virus dari keluarga virus yang dapat menyebabkan penyakit pada manusia dan hewan. Pada manusia biasanya menyebabkan penyakit infeksi saluran pernapasan, mulai dari flu biasa hingga penyakit yang serius. Gejala-gejala Covid - 19 adalah adalah demam, batuk kering, dan rasa 
lelah. Gejala lainnya yang lebih jarang dan mungkin dialami beberapa pasien meliputi rasa nyeri dan sakit, hidung tersumbat, sakit kepala, konjungtivitis, sakit tenggorokan, diare, kehilangan indera rasa atau penciuman. Covid - 19 dapat menyebar melalui percikan-percikan dari hidung atau mulut yang keluar saat orang yang terinfeksi Covid - 19 batuk, bersin atau berbicara.(Nasution et al., 2021)

Berdasarkan data Satuan Tugas Penanganan Covid - 19 terjadi penurunan kasus Covid - 19 di Indonesia setelah diberlakukan PPKM (Perberlakukan Pembatasan Kegiatan Masyarakat). Kabupaten Pati berstatus PPKM level 2, sehingga berdasarkan aturan PPKM dari Kemendikbud Pembelajaran Tatap Muka (PTM) terbatas dapat dilakukan pada satuan pendidikan di wilayah PPKM level 1-3. Maka dari itu beberapa sekolah di Pati sudah dilakukan Pembelajaran Tatap Muka (PTM). Sekolah Dasar di Desa Boloagung sudah mulai melakukan PTM.

Pengabdian ini bertujuan untuk memberikan pengetahuan tentang apa saja yang harus diperhatikan saat sekolah tatap muka kepada anak sekolah dasar. Anak-anak perlu mendapatkan informasi yang memadai dan mudah dipahami agar dapat turut serta melaksanakan beragam upaya pencegahan Covid-19 yang telah dicanangkan oleh pemerinah. Sehingga anak lebih disiplin terhadap protokol kesehatan saat mulai sekolah tatap muka.

\section{Metode}

Kegiatan pengabdian ini dilakukan secara langsung di Desa Boloagung, Kecamatan Kayen, Kabupaten Pati. Kegiatan ini ditujukan untuk anak kelas 1 sampai dengan kelas 6. Program ini dilaksanakan pada hari Selasa, 14 September 2021. Kegiatan ini dimulai dengan memberitahukan kepada anak - anak akan diadakan sosialisasi dengan cara mewarnai media gambar. Lalu meminta peserta untuk membawa pensil warna/crayon. Kemudian pada pelaksaannya peserta diminta untuk mewarnai gambar yang berisi tentang protokol kesehatan yang harus diterapkan saat di sekolah. Selama kurang lebih 1 jam peserta mewarnai gambar tersebut. Setelah selesai diberikan penjelasan kepada anak - anak tentang maksud dari gambar tersebut. Untuk mengevaluasi kegiatan ini dilakukan sesi tanya jawab, untuk mengetahui apakah anak - anak sudah memahami maksud dari gambar tersebut.

Sosialisasi ini dilakukan dengan media gambar yang disajikan adalah dalam bentuk rangkaian gambar yang sederhana berisi pesan secara ringkas, dan informasi. Media gambar digunakan karena menarik dan lebih dimengerti oleh anak - anak. Selain itu, dengen metode mewarnai gambar dapat meningkatkan kreativitas anak. (Mulyaningrum, 2014). Metode ini dipilih karena sesuai tingkat perkembangan anak sekolah dasar yaitu tahap konkrit. Pada tahap ini anak diajak untuk menemukan pengetahuannya sendiri melalui aktivitas yang dilakukannya sehingga anak akan lebih aktif, kreatif dan merasa senang. Hal ini sejalan dengan teori konstruktivisme. Annak membangun keyakinan dan pemahaman berdasarkan pengalaman mereka. (Fitriani et al., 2020)

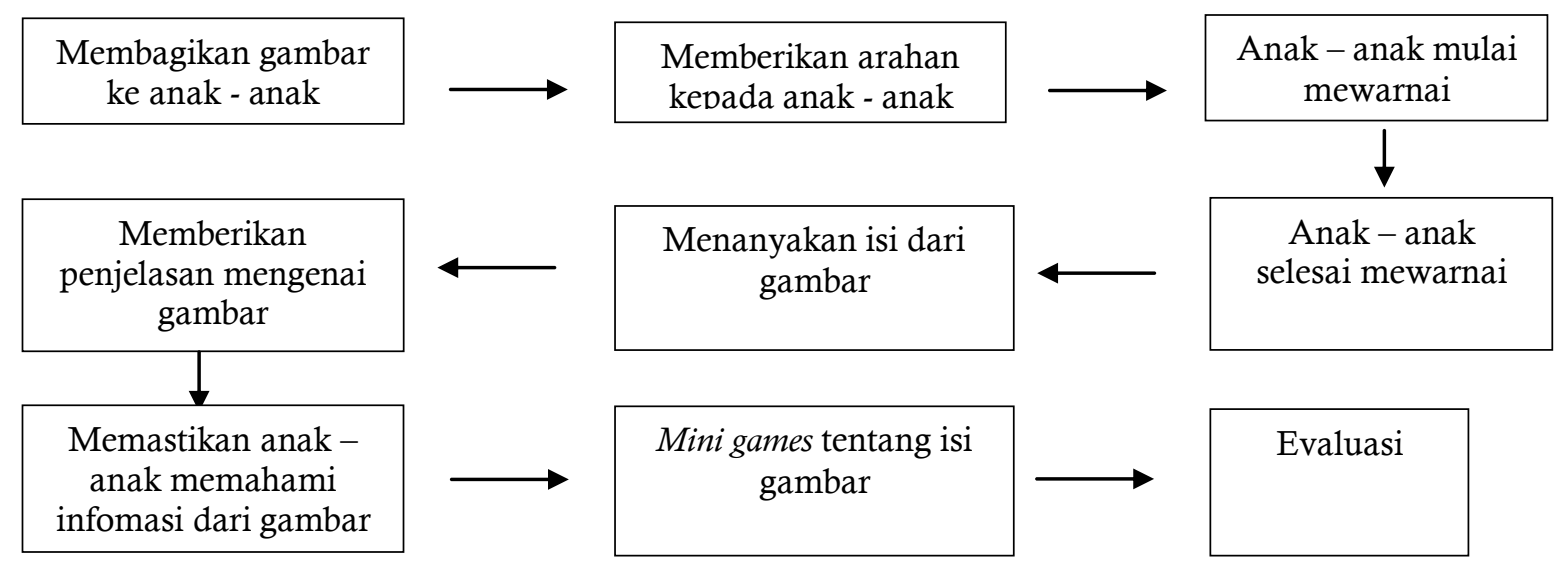

Gambar 1. Proses Sosialisasi kepada Anak - anak

\section{Hasil dan Pembahasan}

Hasil dari pengabdian ini adalah Program ini diikuti oleh anak - anak di Desa Boloagung, Kecamatan Kayen, Kabupaten Pati. Kegiatan ini diikuti sebanyak 21 anak yang terdiri dari 5 anak kelas 1; 6 anak kelas 2; 4 anak kelas 3; 2 anak kelas 4; 3 anak kelas 5 dan 1 anak kelas 6. Selain anak - anak, beberapa orang tua juga ikut menyasikkan program ini. 
Pada program pengabdian masyarakat ini, peserta diberikan media gambar mengenai protokol kesehatan yang harus diterapkan saat sekolah tatap muka di masa pandemi Covid-19. Setelah dilaksanakannya kegiatan ini, siswa sekolah dasar lebih paham mengenai Covid-19. Sosialisasi ini menjelaskan mulai cara mencegahnya, apa saja hal-hal yang harus diperhatikan, serta akibatnya. Dengan begitu siswa sekolah dasar jadi tahu pentingnya menerapkan protokol kesehatan ketika sekolah tatap muka berlangsung. Adanya program ini siswa lebih disiplin dalam menerapkan protokol kesehatan.

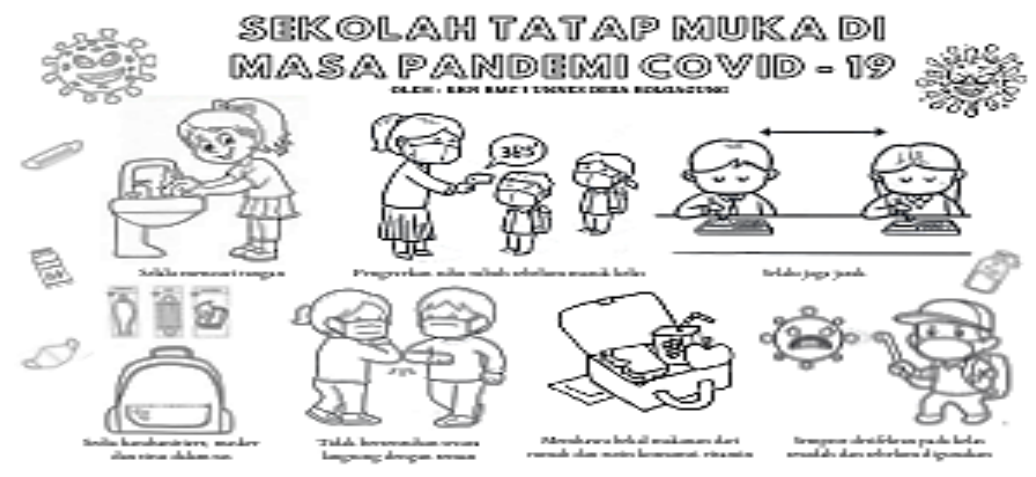

Gambar 1. Media Gambar yang Digunakan dalam Program Pengabdian

Para peserta sangat antusias mengikuti kegiatan ini dilihat dari kedatangan peserta yang lebih awal. Selain itu juga mempersiapkan seperti pensil warna, crayon, dan spidol warna untuk kegiatan ini. Selama kegiatan berlangsung peserta mengikuti arahan dan memperhatikan dengan seksama penjelasan yang disampaikan. Saat mewarnai gambar peserta juga bersungguh - sungguh dalam mawarnai dapat dilihat dari hasil gambar yang diwarnai.

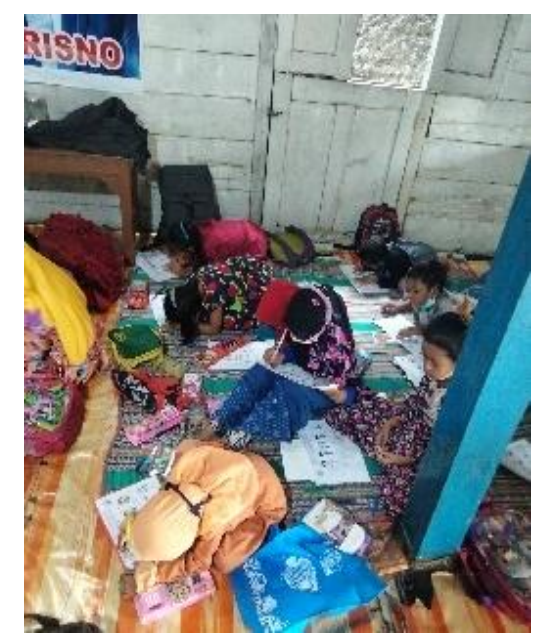

Gambar 2. Kegiatan Mewarnai Gambar

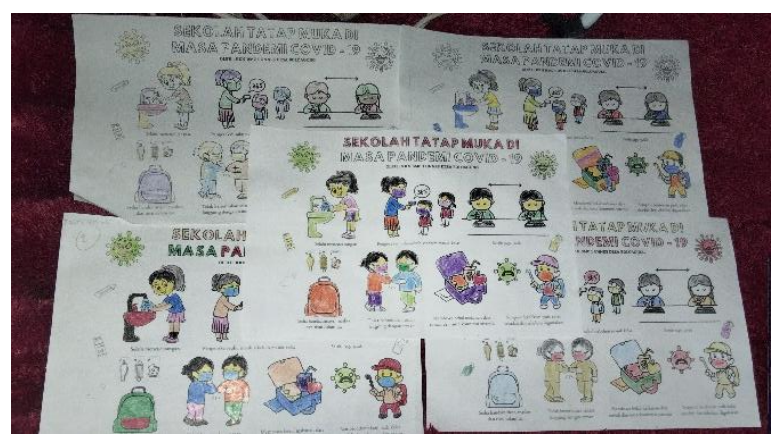

Gambar 3. Hasil Mewarnai Gambar 
Setelah proses mewarnai berlangsung, lalu diberikan penjelasan secara detail mengenai maksud gambar tersebut. Penyampaian pesan terkait adanya pandemi Covid-19 kepada anak tentu berbeda dengan penyampaian pesan kepada orang dewasa. Sebab pola komunikasi anak dan tingkat berpikir anak yang berbeda dengan orang dewasa. Maka dari itu penyampaian pesan atau materi edukasi Covid-19 bagi anak harus menggunakan bahasa yang mudah dipahami dan metode yang sederhana serta menyenangkan. Isi dari gambar tersebut terdiri beberapa cara yang dilakukan saat sekolah tatap muka nanti, diantaranya:

1. Selalu mencuci tangan

2. Dilakukan pengecekan suhu tubuh sebelum masuk kelas

3. Selalu jaga jarak baik dengan teman atau guru

4. Sedia handsanitizer, masker, dan tissu dalam tas

5. Tidak bersentuhan secara langsung dengan teman atau guru

6. Membawa bekal makanan dari rumah dan rutin mengkonsumsi vitamin

7. Semprot desifektan pada saat sebelum dan sesudah kelas digunakan

Untuk mengevaluasi kegiatan ini dilakukan sesi tanya jawab kepada peserta. Peserta antusias untuk menjawab dan saling rebutan untuk menjawab. Bagi peserta yang bisa menjawab atau berani maju ke depan diberikan sedikit apresiasi berupa hadiah. Dilihat dari sesi tanya jawab, peserta sudah dapat mengerti apa yang dijelaskan.

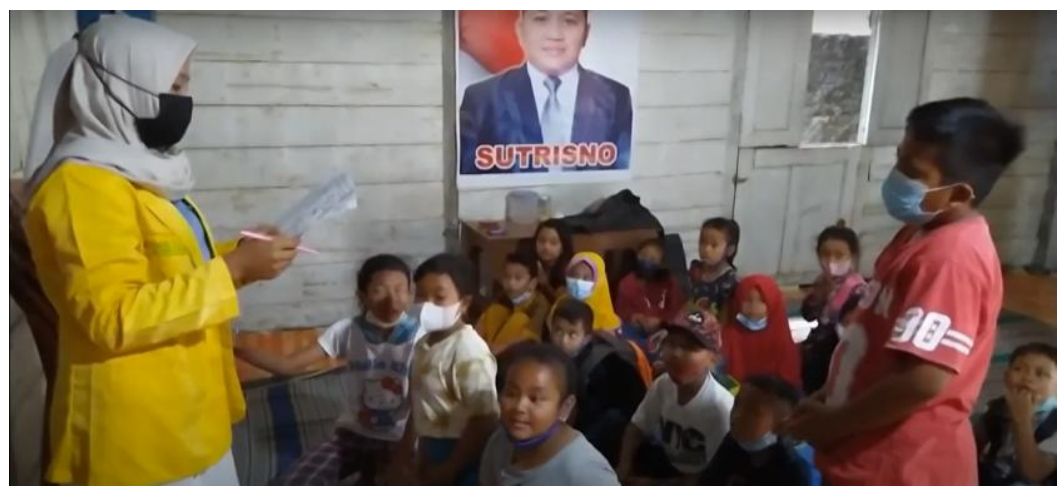

Gambar 4. Sesi tanya jawab

Pada pengabdian ini dilakukan dengan cara komunikasi antarpribadi. Komunikasi antarpribadi dianggap sebagai jenis komunikasi yang paling efektif karena terjadinya kontak langsung, umpan balik yang cepat, saluran atau media yang efektif serta melibatkan perasaan dan gesture. Media visual yaitu media gambar yang digunakan untuk sosialisasi memiliki beberapa kelebihan diantaranya (Pramana et al., 2020):

1. Manusia cenderung berpikir visual

2. Media visual meningkatkan daya ingat

3. Media visualisasi dapat memperkuat organisasi materi sosialisasi

Visualisasi adalah proses dimana ide, konsep dan proses diubah melalui simbol-simbol visual dan gambar.

4. Visualisasi memperkecil kesalah pahaman

Media visual berfungsi memperlancar pemahaman, memperkuat ingatan, menumbuhkan minat siswa, dan memberikan hubungan antara isi materi dengan dunia nyata. Edukasi Covid-19 melalui media gambar dapat membuat anak-anak lebih aktif dan tertarik, melalui ilustrasi gambar. Ilustrasi dapat memudahkan siswa dalam memahami isi serta menemukan pengetahuannya sendiri. (Fitriani et al., 2020)

Evaluasi dari pengabdian ini adalah pada gambar terdapat tulisan yang berisi informasi tiap ilustrasi. Akan tetapi untuk anak kelas 1 belum bisa membaca sehingga perlu diberikan penjelasan lebih secara lisan agar anak tersebut memahami. Media ini sangat efektif digunakan untuk sosialisasi pada anak - anak. Selain beberapa manfaat yang sudah disebutkan, media ini juga dapat meningkatkan kreativitas anak. Anak juga belajar dengan senang karena dapat berkreasi sesuai dengan keinginan. 


\section{Simpulan}

Berdasarkan kegiatan pengabdian yang telah dilakukan dapat disimpulkan bahwa penggunaan media gambar dapat dijadikan alternatif/cara sederhana untuk sosialisasi kepada anak-anak. Program pengabdian ini mampu meningkatkan kesadaran dan pemahaman anak-anak terhadap virus Covid-19 serta protokol kesehatan yang harus dilakukan. Program ini mampu meningkatkan kreativitas anak. Saran dari pelaksanaan program ini adalah perlu dilakukan pengembangan pada media gambar dan bisa dilakukan demonstrasi secara langsung.

\section{Referensi}

Fitriani, A., Maulidya, I. Z., Salafudzin, A., Izza, N. B., \& Moh Izza Assyaefi. (2020). Ed.Cofid (Education Covid-19 For Kids) Dalam Rangka Pencegahan Penyebaran Virus Covid-19 Kepada Anak-Anak Sekolah Dasar Di Desa Wonorejo Karanganyar Demak. Universitas Negeri Semarang : KKN BMC

Marwanto, A. (2021). Pembelajaran pada Anak Sekolah Dasar di Masa Pandemi Covid 19. Jurnal Basicedu, 5(4), 2097-2105.

Mulyaningrum, E. (2014). Pengembangan Kemampuan Kreativitas Melalui Media Mewarnai Gambar Pada Anak Kelompok A Tk Pertiwi I Metuk, Mojosongo, Boyolali Tahun Pelajaran 2013/2014. Jurnal Publikasi.

Nasution, N. H., Hidayah, A., Sari, K. M., Cahyati, W., Khoiriyah, M., Hasibuan, R. P., Lubis, A. A., \& Siregar, A. Y. (2021). Gambaran Pengetahuan Masyarakat Tentang Pencegahan Covid-19 Di Kecamatan Padangsidimpuan Batunadua, Kota Padangsidimpuan Nurul. Jurnal Kesehatan Ilmiah Indonesia, 6(1), 107-114.

Pramana, Utari, P., \& Slamet, Y. (2020). Penggunaan Media Visual dalam Sosialisasi Taat Protokol Kesehatan sebagai Upaya Pencegahaan Penularan Covid-19 di Kabupaten Klaten. Prosiding Seminar Nasional Unimus, 3, 351-357.

Satgas Tugas Penanganan Covid - 19. 2021. Peta Sebaran. https://covid19.go.id/peta-sebaran , diakses pada tanggal 19 September 2021 pukul 22.34 . 